\title{
Characterization of innate and adaptive immune cells involved in the foreign body reaction to polypropylene meshes in the human abdomen
}

\author{
A. Dievernich ${ }^{1}$ (D) P. Achenbach ${ }^{2} \cdot$ L. Davies $^{3} \cdot$ U. Klinge $^{1}$
}

Received: 23 December 2020 / Accepted: 10 March 2021 / Published online: 31 March 2021

(C) The Author(s) 2021

\begin{abstract}
Background Polypropylene (PP) mesh is widely used to reinforce tissues. The foreign body reaction (FBR) to the implant is dominated by innate immune cells, especially macrophages. However, considerable numbers of adaptive immune cells, namely $\mathrm{T}$ cells, have also been regularly observed, which appear to play a crucial role in the long-term host response.

Methods This study investigated the FBR to seven human PP meshes, which were removed from the abdomen for recurrence after a median of one year. Using immunofluorescence microscopy, the FBR was examined for various innate $\left(\mathrm{CD} 11 \mathrm{~b}^{+}\right.$ myeloid, $\mathrm{CD}^{+} 8^{+}$macrophages, $\left.\mathrm{CD} 56^{+} \mathrm{NK}\right)$ and adaptive immune cells $\left(\mathrm{CD} 3^{+} \mathrm{T}, \mathrm{CD} 4^{+}\right.$T-helper, $\mathrm{CD} 8^{+}$cytotoxic, FoxP3 ${ }^{+}$ T-regulatory, $\mathrm{CD} 20^{+} \mathrm{B}$ ) as well as "conventional" immune cells (defined as cells expressing their specific immune cell marker without co-expressing CD68).

Results T-helper cells (19\%) and regulatory T-cells (25\%) were present at comparable rates to macrophages, and clustered significantly toward the mesh fibers. For all cell types the lowest proportions of "conventional" cells $(<60 \%)$ were observed at the mesh-tissue interface, but increased considerably at about 50-100 $\mu \mathrm{m}$, indicating reduced stimulation with rising distance to the mesh fibers.

Conclusion Both innate and adaptive immune cells participate in the chronic FBR to PP meshes with T cells and macrophages being the predominant cell types, respectively. In concordance with the previous data, many cells presented a "hybrid" pattern near the mesh fibers. The complexity of the immune reaction seen within the foreign body granuloma may explain why approaches focusing on specific cell types have not been very successful in reducing the chronic FBR.
\end{abstract}

Keywords Foreign body reaction · Adaptive immune system · Innate immune system · Mesh · Fluorescence microscopy

\section{Introduction}

Polypropylene (PP) meshes are widely used in surgery to reinforce tissues, in particular for the treatment of abdominal wall hernia or pelvic floor instability. After implantation of biomaterials, blood/material interactions occur first,

A. Dievernich

adievernich@web.de

1 Department of General, Visceral and Transplant Surgery, RWTH Aachen University Hospital, Pauwelsstraße 30, 52074 Aachen, Germany

2 Institute of Neuropathology, RWTH Aachen University Hospital, Aachen, Germany

3 Division of Infection and Immunity, Cardiff University, Cardiff, UK followed by migration of immune cells marking the onset of inflammation, development of granulation tissue, and remodeling with formation of a fibrous capsule that shields the foreign body $[1,2]$. The tissues reaction to the implant is dominated by cells of the innate immune system, especially $\mathrm{CD}^{+} 8^{+}$macrophages [3]. The morphologic structure consisting of cellular infiltrate and fibrotic capsule is denoted foreign body granuloma (FBG). Owing to their persistence at the mesh-tissue interface, macrophages are held responsible for the chronic inflammatory process. However, considerable numbers of lymphocytes have also been regularly observed in the FBG [4].

Granulomatous inflammation is a hallmark in several infectious (e.g., mycobacterial) and noninfectious (e.g., sarcoidosis, Crohn's disease) diseases in response to persistent stimuli [5-8]. The central part of the granulomas usually consists of various macrophage populations and sparse 
multinucleated giant cells surrounded by a lymphatic cuff of T- and B-cells as well as fibroblasts, with mature granulomas also featuring a fibrotic layer [5, 6, 9-11]. However, the architecture and immunology of granuloma formation differ significantly between granulomatous disorders [12]. The FBG is considered the most basic form of granulomatous inflammation, which fundamentally differs from granulomatous diseases because foreign bodies do not prominently feature adaptive immune responses $[12,13]$.

Classically, host immunity is separated into the innate (fast and unspecific) immunity mediated by myeloid cells, such as macrophages and natural killer (NK) cells, and the adaptive (slower but specific) immunity based on B- and T-lymphocytes [14]. Although Mills et al. already postulated in 2000, a collaboration between macrophages and lymphocytes, innate, and adaptive immune processes were long regarded as separate or relatively compartmentalized in time [15]. However, research over the last decades has clearly demonstrated strong links between both immune systems [14].

In 2019, Tennyson et al. pointed out that cells of the adaptive immune system, namely T-helper cells $\left(\mathrm{CD}^{+}\right)$, cytotoxic T-cells $\left(\mathrm{CD}^{+}\right)$, and regulatory T-cells $\left(\mathrm{FoxP}^{+}\right)$, appear to play a crucial role in the long-term host response to pelvic floor meshes and remain elevated in the FBG years after implantation [16]. Similar results were observed by Artsen et al., although with different implications regarding regulatory T-cells in relation to fibrosis [17]. Although Tennyson et al. suggested that T-helper cells and regulatory T-cells promote a fibrotic response, Artsen et al. concluded that the latter rather have an antifibrotic effect. Obviously, the role of lymphocytes in the foreign body reaction (FBR) to mesh is still matter of debate. Moreover, a possible importance of the adaptive immune system after implantation of PP meshes is underlined by the observations of Cohen Tervaert in 40 patients who developed symptoms of a systemic illness [18]. After complete mesh removal in 6 patients, they recovered (partially), leading the author to postulate that PP mesh as an adjuvant may increase the risk of developing lymphocyte related (auto)immune diseases.

Previously, we reported that CD68 is co-expressed on various cell types participating in the FBR to meshes, which is considered a "hybrid" pattern in contrast to "conventional" cells expressing their specific surface markers without CD68 [19]. Subsequently, we showed that tissue remodeling macrophages dominate at the interface of fibrotic PP meshes in the human abdomen that have been removed for the primary complaint of recurrence [20].

The aim of this study was to further characterize the chronic FBR to the PP meshes, which were removed for recurrence. We analyzed the presence of several innate $\left(\mathrm{CD} 11 \mathrm{~b}^{+}\right.$myeloid cells, $\mathrm{CD} 68^{+}$macrophages, $\mathrm{CD} 56^{+} \mathrm{NK}$ cells) and adaptive $\left(\mathrm{CD}^{+}{ }^{+} \mathrm{T}\right.$ lymphocytes, $\mathrm{CD} 4^{+} \mathrm{T}$-helper cells, $\mathrm{CD} 8^{+}$cytotoxic T-cells, FoxP3 ${ }^{+}$regulatory T-cells, $\mathrm{CD} 20^{+} \mathrm{B}$ lymphocytes) immune cells using immunofluorescence microscopy. We examined the total number and percentages of cells located within a $1 \mathrm{~mm}^{2}$ circular region of interest placed around mesh fibers and their spatial distributions using distance maps. Finally, we looked for the proportions of "conventional" immune cells (defined as cells not co-expressing CD68) relative to the total number of positive cells for each cell type as an indicator of the sustained mesh-induced stimulus.

\section{Materials and methods}

We analyzed new tissue sections from seven polypropylene (PP) meshes that were used for abdominal wall hernia repair; and have been explanted for recurrence after a median incorporation time of 1 year. Medical records were reviewed, and the following meshes were recorded: 3 large pore Ultrapro ${ }^{\circledR}, 2$ small pore plugs, and 2 Ventralex ${ }^{\circledR}$ with a layer of PTFE (Table 1). To minimize the influence of the PTFE layer of Ventralex ${ }^{\circledR}$ meshes, the layer and adjacent cells were spatially excluded (s-Fig. 1). Human tissue samples of liver, lymph node, tonsil, and spleen without gross pathology served as healthy control tissues; and were used to check specificity of labeling and optimize antibody dilutions (s-Fig. 2-4; s-Table 1).

Prior to immunofluorescence staining, mesh samples were checked for the presence of characteristic cells and morphology by hematoxylin and eosin. All mesh-tissue complexes demonstrated a typical, highly localized foreign body reaction around the mesh fibers, consisting of a dense inner cellular infiltrate (predominantly mononuclear cells) surrounded by an outer fibrotic capsule. Morphologically, cellular infiltrates at the mesh-tissue interface always presented a mixture of mainly macrophages and lymphocytes with a few multinucleated foreign body giant cells.

Table 1 Information on the patients whose mesh samples were examined

\begin{tabular}{lllll}
\hline Explant no & Mesh type & $\begin{array}{l}\text { Incorporation } \\
\text { time [years] }\end{array}$ & Gender & Age \\
\hline$\# 1$ & Ultrapro $^{\circledR}$ & 0.6 & Female & 52 \\
$\# 2$ & Ultrapro $^{\circledR}$ & 0.9 & Female & 34 \\
$\# 3$ & Ultrapro $^{\circledR}$ & 1.3 & Female & 50 \\
$\# 4$ & Ventralex $^{\circledR}$ & 1.0 & Male & 47 \\
$\# 5$ & Ventralex $^{\circledR}$ & 6.0 & Female & 57 \\
$\# 6$ & Plug & 2.2 & Male & 69 \\
$\# 7$ & Plug & 4.0 & Male & 51 \\
\hline
\end{tabular}




\section{Immunofluorescent staining}

The staining protocol used for this investigation has already been described in detail before [20]. Briefly, serial $2 \mu \mathrm{m}$ sections of each specimen were double labeled with monoclonal antibodies (Table 2). The order of fluorophores was always kept constant. Tissue sections were deparaffinized, rehydrated before incubation in formalin. Then, antigens were retrieved. Afterwards, sections were washed and cooled before nonspecific binding was blocked. The panmacrophage marker CD68 was applied and labeled with fluorescein isothiocyanate (FITC). Afterwards, tissue sections were microwave treated for antibody stripping and incubated overnight. The second marker was applied the following day and labeled with cyanine-5 (Cy5). The list of second markers includes CD3 [T lymphocytes (T cells)], CD4 [T-helper cells $\left(\mathrm{T}_{\mathrm{h}}\right)$ ], CD8 [cytotoxic T-cells $\left(\mathrm{T}_{\mathrm{c}}\right)$ ], CD11b (myeloid cells), CD20 [B lymphocytes (B cells)], CD56 [natural killer cells (NK cells)], and FoxP3 [regulatory T-cells $\left(\mathrm{T}_{\text {regs }}\right)$ ]. Finally,

Table 2 List of monoclonal antibodies used in this study sorted alphabetically

\begin{tabular}{lllll}
\hline Antibody & Clone & Dilution & Incubation time & Manufacturer \\
\hline CD3 & F7.2.38 & $1: 1000$ & $30 \mathrm{~min}$ & Dako \\
CD4 & 4B12 & $1: 500$ & $30 \mathrm{~min}$ & Dako \\
CD8 & CD8/144B & $1: 500$ & $30 \mathrm{~min}$ & Dako \\
CD11b & OTI12C10 & $1: 2000$ & $30 \mathrm{~min}$ & OriGene \\
CD20 & L26 & $1: 200$ & $30 \mathrm{~min}$ & Dako \\
CD56 & 123C3 & $1: 200$ & $30 \mathrm{~min}$ & Dako \\
CD68 & KP1 & $1: 6000$ & $30 \mathrm{~min}$ & Dako \\
FoxP3 & PCH101 & $1: 250$ & $30 \mathrm{~min}$ & eBioscience \\
\hline
\end{tabular}

tissue sections were rinsed, counterstained with DAPI, and coverslipped.

\section{Analysis of fluorescence images/stainings}

Fluorescence imaging was performed with an Axio Imager 2 epifluorescence microscope ( $20 \times$, Zeiss, Germany) and the TissueFAXS PLUS system (TissueGnostics, Austria). Images were processed and quantitatively analyzed with StrataQuest Analysis Software (v6, TissueGnostics). We performed two separate analysis, the first with selected $1 \mathrm{~mm}^{2}$ circular regions of interest (ROIs) that were placed around mesh fibers and the second with manually outlined individual mesh fiber areas that were processed using Euclidean distance to establish distance maps with six regional zones (zone1: 0-50 $\mu \mathrm{m}$, zone2: $50-100 \mu \mathrm{m}$, zone3: 100-150 $\mu \mathrm{m}$, zone4: $150-200 \mu \mathrm{m}$, zone 5: $200-250 \mu \mathrm{m}$, zone6: $250-350 \mu \mathrm{m}$ ) from the mesh fibers (Fig. 1). A median of 10 (range 5-28) ROIs and 35 (range 17-86) individual mesh fiber areas were analyzed. The detection of cells and positive marker signals was done as described previously [19]. Briefly, optimized DAPI images were used to detect and segment nuclei whose areas were used to measure the mean staining intensities for FITC- and Cy5-shades of the respective markers. Cells with a mean staining intensity above 100 were considered "positive" and detection was verified with backward gating (Fig. 2). We recorded the total number of nuclei, as well as the percentages of FITC $^{+}$ $\left(\mathrm{CD}^{+} 8^{+}\right), \mathrm{Cy}^{+}$(second marker $^{+}$), and $\mathrm{Cy}^{+}{ }^{-} \mathrm{FITC}^{-}$(second marker $\left.{ }^{+} \mathrm{CD} 68^{-}\right)$cells.

In addition, controls without primary antibody and controls with isotype antibodies were performed. The omission of the primary antibodies and substitution of the
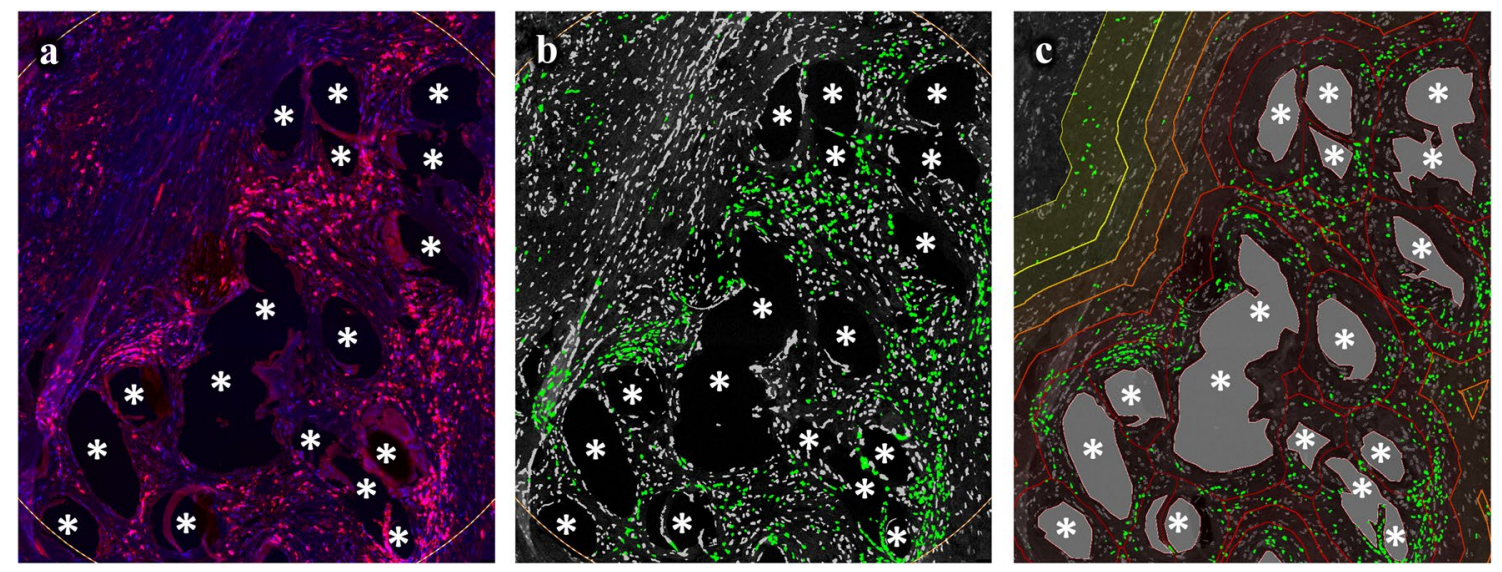

Fig. 1 Immunofluorescence labeling of T cells (CD3) with region of interest (ROI) and distance map analysis. a Labeling of T cells with Cy5 (red) and nuclei with DAPI (blue). b Backward gating of $\mathrm{CD}^{+}$ $\mathrm{T}$ cells (green) using ROI analysis. $\mathbf{c}$ Backward gating of $\mathrm{CD}^{+} \mathrm{T}$ cells (green) with superimposed distance map. Backward gating is always on the nuclei shade. The Euclidean distance map consists of six regional zones from $0-50 \mu \mathrm{m}$ (dark red) to $250-350 \mu \mathrm{m}$ (bright yellow) in $50 \mu \mathrm{m}$ steps. Locations of mesh fibers are marked with asterisks, scale bar $=100 \mu \mathrm{m}$. Images of explant \#3 (color figure online) 

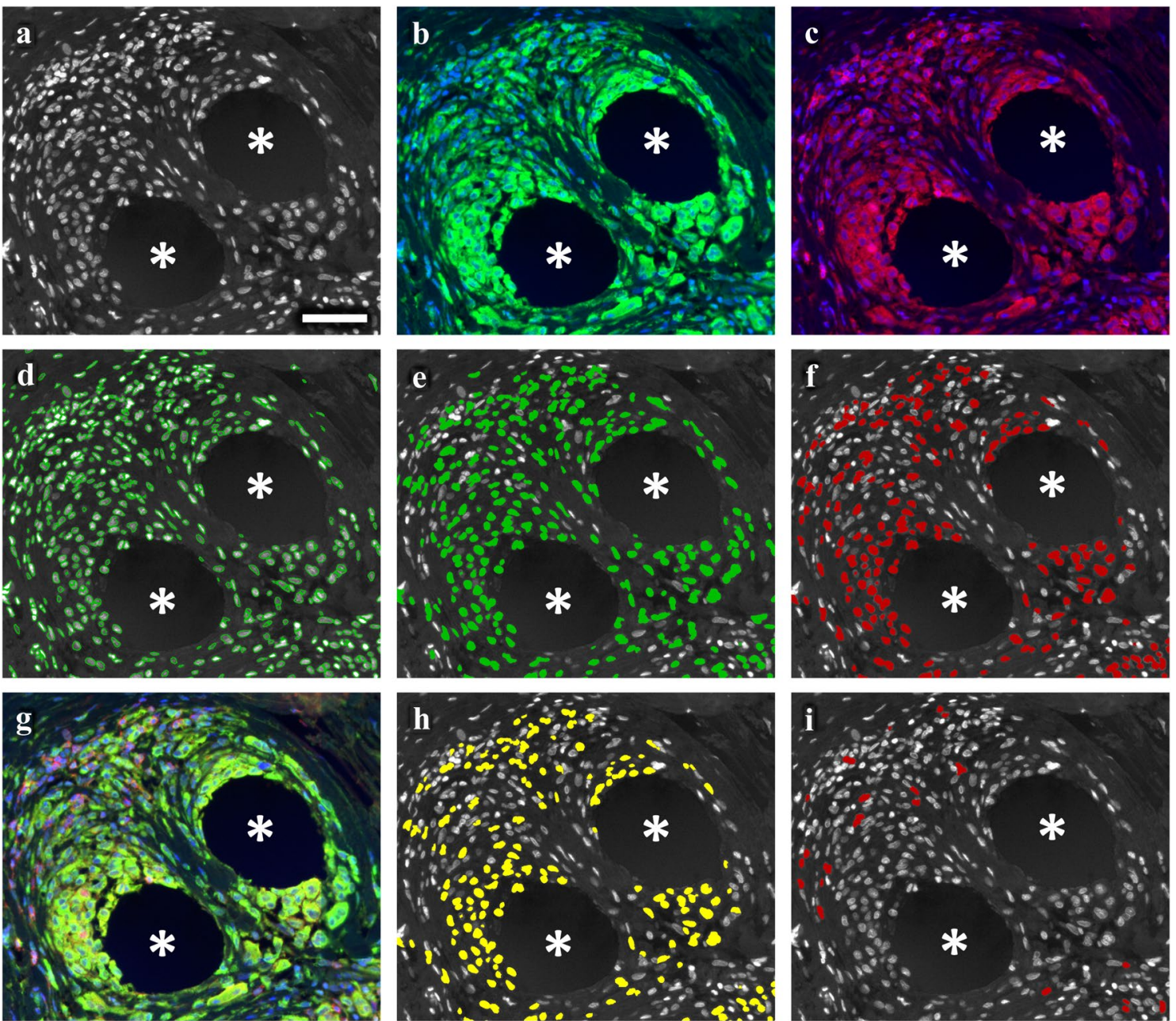

Fig. 2 Nuclear detection and backward gating of immune cells participating in the foreign body reaction. Immunofluorescence labeling of pan-macrophage marker CD68 (FITC), CD4 (Cy5), and nuclei (DAPI). a Grayscale nuclei shade. b CD68 (green) and nuclei (blue). c CD4 (red) and nuclei (blue). d Backward gating of detected nuclei (green contours). e Backward gating of $\mathrm{CD}^{+} 8^{+}$cells (green). f Backward gating of $\mathrm{CD}^{+}$cells (red). g Superposition of CD68 (green), CD4 (red) and nuclei (blue). h Backward gating of "hybrid" $\mathrm{CD} 4{ }^{+} \mathrm{CD} 68^{+}$cells (yellow). i Backward gating of "conventional" $\mathrm{CD} 4^{+} \mathrm{CD}^{-} 8^{-}$cells (red). Backward gating is always on the nuclei shade. Locations of mesh fibers are marked with asterisks, scale bar $=50 \mu \mathrm{m}$. Images of explant \#3 (color figure online) primary antibodies with the isotype antibodies at the same final concentrations resulted in lack of immunostaining.

\section{Statistical analysis}

Calculations were done with MATLAB ${ }^{\circledR} 9.1$ and Image Processing Toolbox 9.5 (The MathWorks, US). Statistical analysis was performed with Statistical Package for Social Sciences software (SPSS ${ }^{\circledR}$ v23, IBM, US). Statistical significance between different zones were determined with Mann-Whitney $U$ test, $p$ values $<0.05$ were considered to be statistically significant.

\section{Results}

\section{Innate and adaptive immune cells co-exist within the foreign body granuloma}

By using $1 \mathrm{~mm}^{2}$ circular regions of interest (ROIs) placed around mesh fibers, we studied the cell densities, defined as cells per $\mathrm{mm}^{2}$ as well as the percentages of innate (macrophages, $\mathrm{NK}$ cells, $\mathrm{CD} 11 \mathrm{~b}^{+}$cells) and adaptive (T cells, $\mathrm{T}_{\mathrm{h}}, \mathrm{T}_{\mathrm{c}}, \mathrm{T}_{\mathrm{regg}}, \mathrm{B}$ cells) immune cells (as fraction of total cells). Within the ROI the cell density varied between 2,700 and 3,600 cells $/ \mathrm{mm}^{2}$, depending on the area of mesh 
fibers contained in the ROIs. As expected, the foreign body reaction of the mesh-tissue complexes within the ROI presented a high proportion of innate immune cells, with $25 \% \mathrm{CD}^{2} 8^{+}$macrophages, $20.2 \% \mathrm{CD}^{11 \mathrm{~b}^{+}}$myeloid cells, and 9.8\% CD56 ${ }^{+}$NK cells (Table 3; Figs. 3-4). However, adaptive immune cells were also frequently observed, ranging from $5.2 \%$ for $\mathrm{CD} 20^{+} \mathrm{B}$ cells to $24.7 \%$ for $\mathrm{FoxP}^{+} \mathrm{T}_{\text {regs }}$. The mean $\mathrm{CD} 4^{+} / \mathrm{CD}^{+}$ratio was 1.7 with a standard error of 0.5 , indicating overall well-functioning patient immune systems $\left(\mathrm{CD}^{+} / \mathrm{CD}^{+}\right.$ratio $\left.>1\right)$ [21].

\section{Innate and adaptive immune cells cluster toward the mesh fibers}

Calculation of distance maps allowed to analyze the spatial distribution of the immune cells within the foreign body granuloma (FBG) (Fig. 5). In concordance with the previous data [20], the analysis revealed a significantly decreasing cell density and number of $\mathrm{CD} 68^{+}$macrophages with distance to the mesh fibers, from 4,418 cells $/ \mathrm{mm}^{2}$ in zone1 $(0-50 \mu \mathrm{m})$ to 1,696 cells $/ \mathrm{mm}^{2}$ in zone6 $(250-350 \mu \mathrm{m})$, and from 45.4 to $9.7 \%$, respectively (Table 4; Fig. 6). For a rising distance up to 100 and $150 \mu \mathrm{m}$ a decrease was also observed for $\mathrm{CD}^{2} 6^{+} \mathrm{NK}$ cells and CD11 $\mathrm{b}^{+}$myeloid cells. The highest frequencies of adaptive immune cells were observed in zone1 and zone2 $(0-100 \mu \mathrm{m})$, except for CD20 $0^{+}$B cells, which were generally rare (Table 5; Fig. 6). Interestingly, however, dense clusters of $\mathrm{B}$ cells were frequently observed clustered around blood vessels near the FBG (Fig. 7). Except for B cells and NK cells, all investigated cell types decreased significantly from zone1 to zone6 (Tables 4, 5).

\section{Proportions of "conventional" immune cells increase with distance to the mesh fibers}

Previously, we reported that in the area of the granuloma CD68 is co-expressed on various cell types participating in the FBR, which is considered a "hybrid" pattern due to the sustained mesh-induced stimulus [19]. This co-expression is rarely present $(<5 \%)$ in control tissues (s-Table 1$)$. In this study, we confirmed the abundant co-expression of CD68 in various types of immune cells (Fig. 8). To investigate at what distance the immune cells transition toward a more physiological "conventional" state marked by low CD68 coexpression, we looked for the fraction of the total number of positive cells for each cell type not co-expressing CD68, e.g., $\mathrm{CD} 4^{+} \mathrm{CD} 68^{-} / \mathrm{CD}^{+}$for $\mathrm{T}_{\mathrm{h}}$, in relation to the distance of the mesh fibers.

Overall, within the FBG, $\mathrm{CD} 4^{+} \mathrm{T}_{\mathrm{h}}$ presented the lowest proportion of "conventional" cells with $38.1 \%$, while $\mathrm{CD} 20^{+} \mathrm{B}$ cells presented the highest with $71.3 \%$ (Table 3 ). Spatial analysis with distance maps revealed for all investigated cell types the lowest proportion of "conventional" cells in zone $1(0-50 \mu \mathrm{m})$ directly at the mesh-tissue interface, with the lowest proportion for $\mathrm{CD}^{+} 6^{+} \mathrm{NK}$ cells $(18.1 \%)$ and the highest for $\mathrm{CD} 20^{+} \mathrm{B}$ cells (57.3\%) (Tables 4, 5; Fig. 9). From zone1 to zone2 $(50-100 \mu \mathrm{m})$, the proportion of "conventional" cells increased for all cell types, but being significant only for $\mathrm{CD}^{+} \mathrm{T}_{\mathrm{h}}, \mathrm{CD}^{+} \mathrm{T}_{\mathrm{c}}, \mathrm{FoxP}^{+} \mathrm{T}_{\text {regs }}, \mathrm{CD} 11 \mathrm{~b}^{+}$ myeloid cells, and $\mathrm{CD} 56^{+} \mathrm{NK}$ cells. Noteworthy, from zone2 to zone6 $(250-350 \mu \mathrm{m})$, the proportions remained relatively constant except FoxP3 ${ }^{+} \mathrm{T}_{\text {regs }}$ and CD56 $6^{+} \mathrm{NK}$ cells, whose proportions increased steadily with distance to the mesh fibers (Tables 4, 5).
Table 3 Analysis of innate and adaptive immune cells participating in the foreign body reaction to polypropylene meshes using regions of interest

\begin{tabular}{|c|c|c|c|c|c|c|}
\hline \multirow[t]{2}{*}{$\begin{array}{l}\text { Marker ( } n=7 \text { PP } \\
\text { meshes) }\end{array}$} & \multicolumn{2}{|c|}{ Cell density (cells/mm²) } & \multicolumn{2}{|c|}{$\%$ Marker $^{+} /$Nuclei } & \multicolumn{2}{|c|}{$\begin{array}{l}\text { \% } \text { Marker }^{+} \mathrm{CD}^{-} / \\
\text {Marker }^{+} \\
\text {"conventional" }\end{array}$} \\
\hline & Mean & SE & Mean & SE & Mean & SE \\
\hline \multicolumn{7}{|l|}{ Adaptive } \\
\hline $\mathrm{CD}^{+}$ & $3,313.5$ & 152.6 & 18.2 & 1.0 & 64.5 & 2.1 \\
\hline $\mathrm{CD}^{+}$ & $3,584.1$ & 137.5 & 19.2 & 1.3 & 38.1 & 2.2 \\
\hline $\mathrm{CD}^{+}$ & $3,521.2$ & 164.9 & 13.5 & 1.0 & 53.1 & 2.3 \\
\hline $\mathrm{CD} 20^{+}$ & $3,184.1$ & 105.5 & 5.2 & 0.9 & 71.3 & 3.8 \\
\hline FoxP3 $^{+}$ & $2,737.6$ & 51.4 & 24.7 & 1.0 & 57.9 & 1.3 \\
\hline \multicolumn{7}{|l|}{ Innate } \\
\hline $\mathrm{CD}_{11} \mathrm{~b}^{+}$ & $3,065.7$ & 102.5 & 20.2 & 1.5 & 52.0 & 2.1 \\
\hline $\mathrm{CD}_{5} 6^{+}$ & $3,108.3$ & 80.0 & 9.8 & 1.1 & 45.2 & 2.6 \\
\hline $\mathrm{CD} 8^{+}$ & $3,206.1$ & 51.6 & 25.0 & 0.5 & - & - \\
\hline
\end{tabular}

The cell density is defined as the mean number of cells per $\mathrm{mm}^{2}$. Percentages of single-positive (Marker ${ }^{+}$) cells in relation to all cells and the proportions of "conventional" $\left(\right.$ Marker $^{+} \mathrm{CD} 68^{-}$) cells as function of all Marker ${ }^{+}$cells. Hybrid cells with co-expression of CD68 were considered "disturbed" 
Fig. 3 Region of interest selection and immunofluorescence labeling of immune cells part1. Labeling of T cells (CD3), $\mathrm{T}_{\mathrm{h}}$ (CD4), $\mathrm{T}_{\mathrm{c}}(\mathrm{CD} 8)$, and $\mathrm{T}_{\text {regs }}$ (CD8). Nuclei are labeled with DAPI (blue). a-d Labeling of cells with Cy5 (red) and $\mathbf{e - h}$ backward gating of "positive" cells (green), respectively. Cells with a mean staining intensity $>100$ are considered to be "positive". Locations of mesh fibers are marked with asterisks, scale bar $=100 \mu \mathrm{m}$. Images of explants \#7 (color figure online)
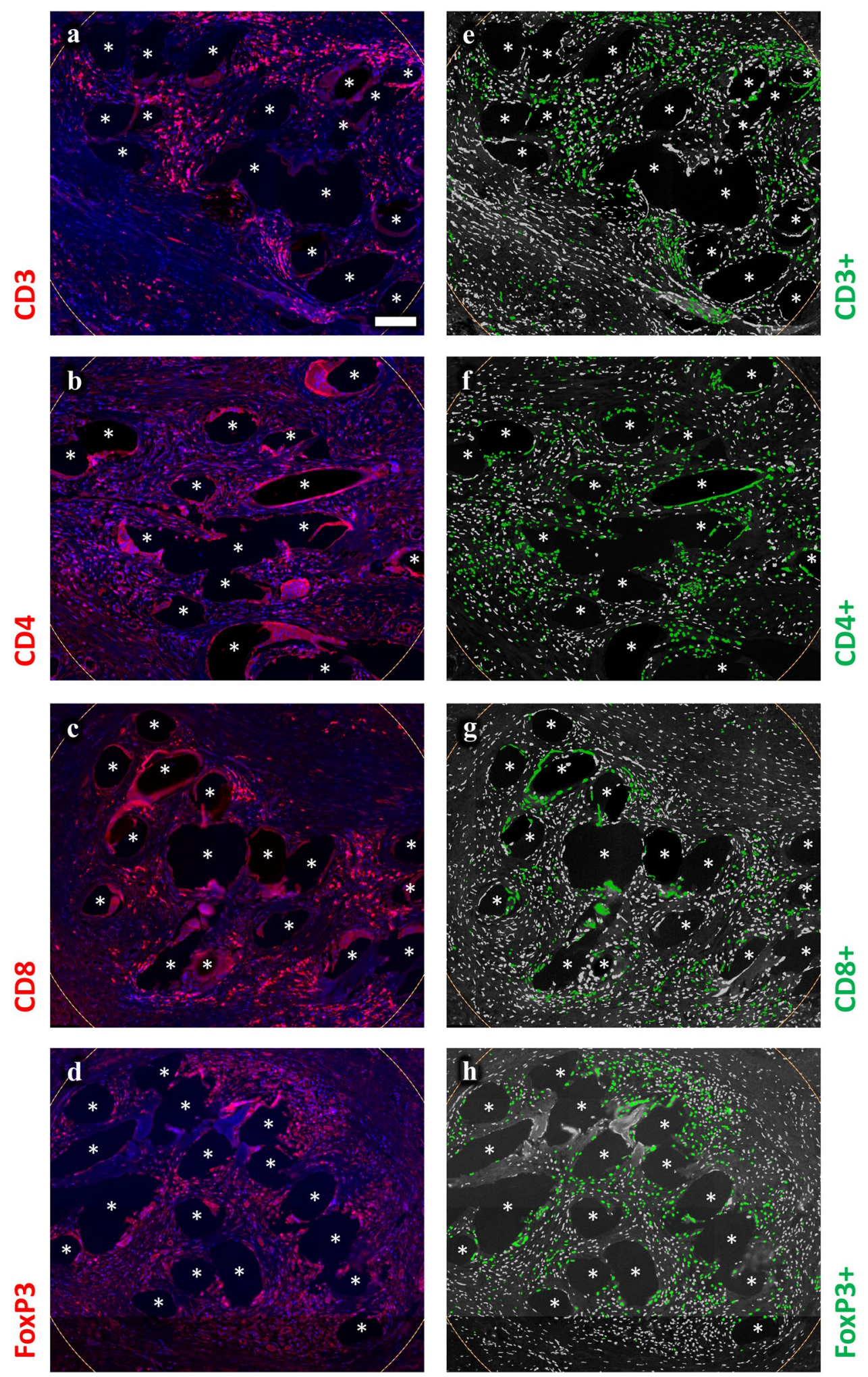

\section{Discussion}

The study of innate and adaptive immune cells in human polypropylene (PP) mesh explants from the abdomen clearly demonstrates that cells from both arms of the immune system participate in the foreign body reaction (FBR) after implantation. 
Fig. 4 Region of interest selection and immunofluorescence labeling of immune cells part2. Labeling of B cells (CD20), NK cells (CD56), myeloid cells (CD11b), and macrophages (CD68). Nuclei are labeled with DAPI (blue). a-d Labeling of cells with Cy5 (red) and $\mathbf{e}-\mathbf{h}$ backward gating of "positive" cells (green), respectively. Cells with a mean staining intensity $>100$ are considered to be "positive". Locations of mesh fibers are marked with asterisks, scale bar $=100 \mu \mathrm{m}$. (a, e) Images of explant \#6, (b, f) images of explant \#2, (c, d, $\mathbf{g}$, h) images of explant \#3 (color figure online)
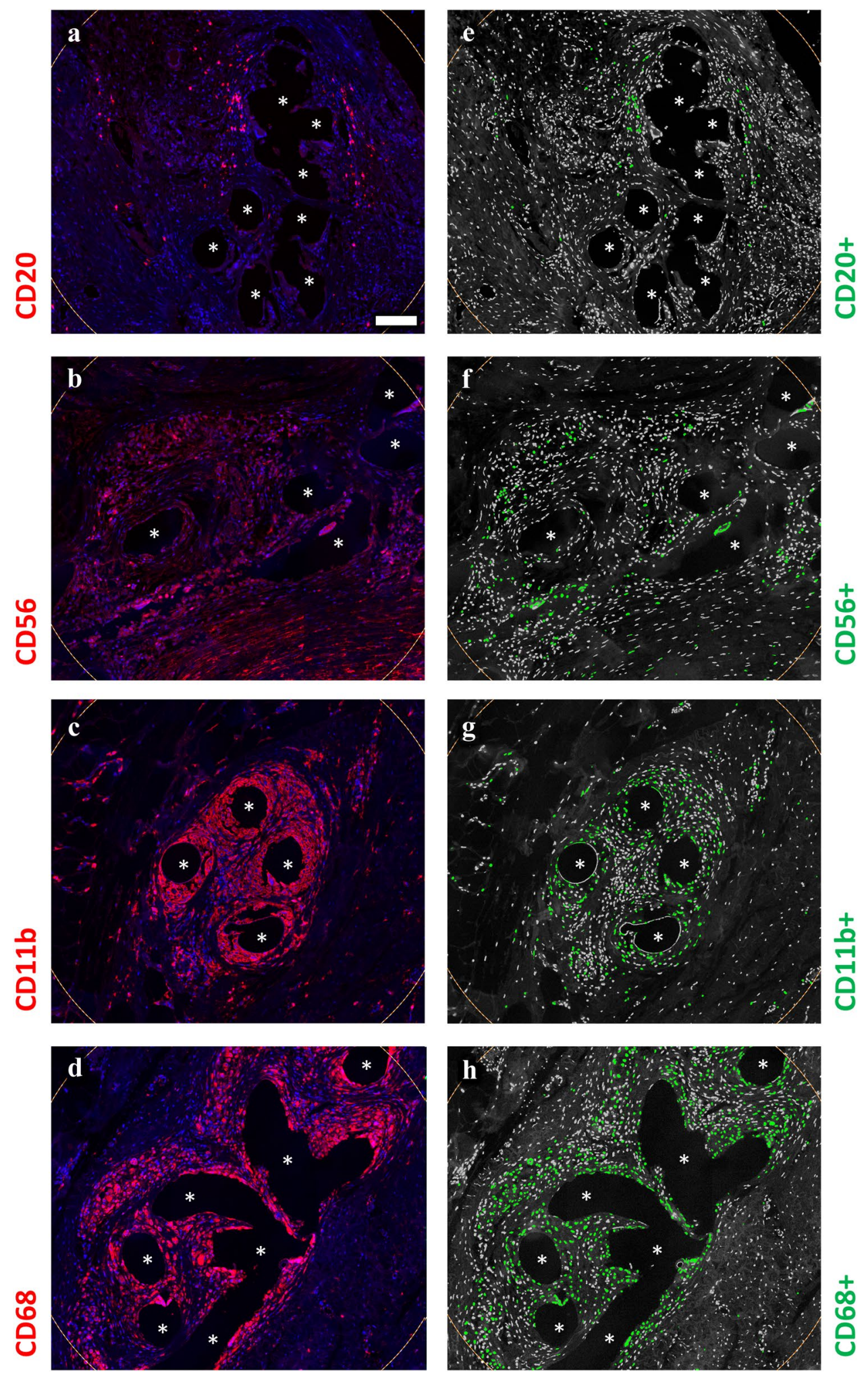

Lymphocytes, such as $\mathrm{T}_{\mathrm{h}}$ and $\mathrm{T}_{\text {regs }}$ were present at comparable rates to macrophages (25\%) with $19.2 \%$ and $24.7 \%$, respectively, demonstrating that both innate and adaptive cells are likely to collaborate in the foreign body granuloma
(FBG). Furthermore, all investigated immune cell types significantly accumulate in vicinity of the mesh fibers, except for NK and B cells. Irrespective of individual clustering, all cell types at the interface $(0-50 \mu \mathrm{m})$ showed "disturbance" 
Fig. 5 Spatial analysis of immunofluorescence labeled immune cells using Euclidean distance maps. Labeling of $\mathrm{T}$ cells (CD3), $\mathrm{T}_{\mathrm{h}}(\mathrm{CD} 4), \mathrm{T}_{\mathrm{c}}$ (CD8), and $\mathrm{T}_{\text {regs }}(\mathrm{CD} 8)$. Nuclei are labeled with DAPI (blue). a-d Labeling of immune cells with Cy5 (red) and e-h backward gating of "positive" cells (green) with superimposed distance map, respectively.

The Euclidean distance map consists of six regional zones from $0-50 \mu \mathrm{m}$ (dark red) to 250-350 $\mu \mathrm{m}$ (bright yellow) in $50 \mu \mathrm{m}$ steps. Locations of mesh fibers are marked with asterisks, scale bar $=100 \mu \mathrm{m}$. Images of the other cell types with distance maps are provided in the supplementary file (s-Fig. 5). Images of explant \#7 (color figure online)
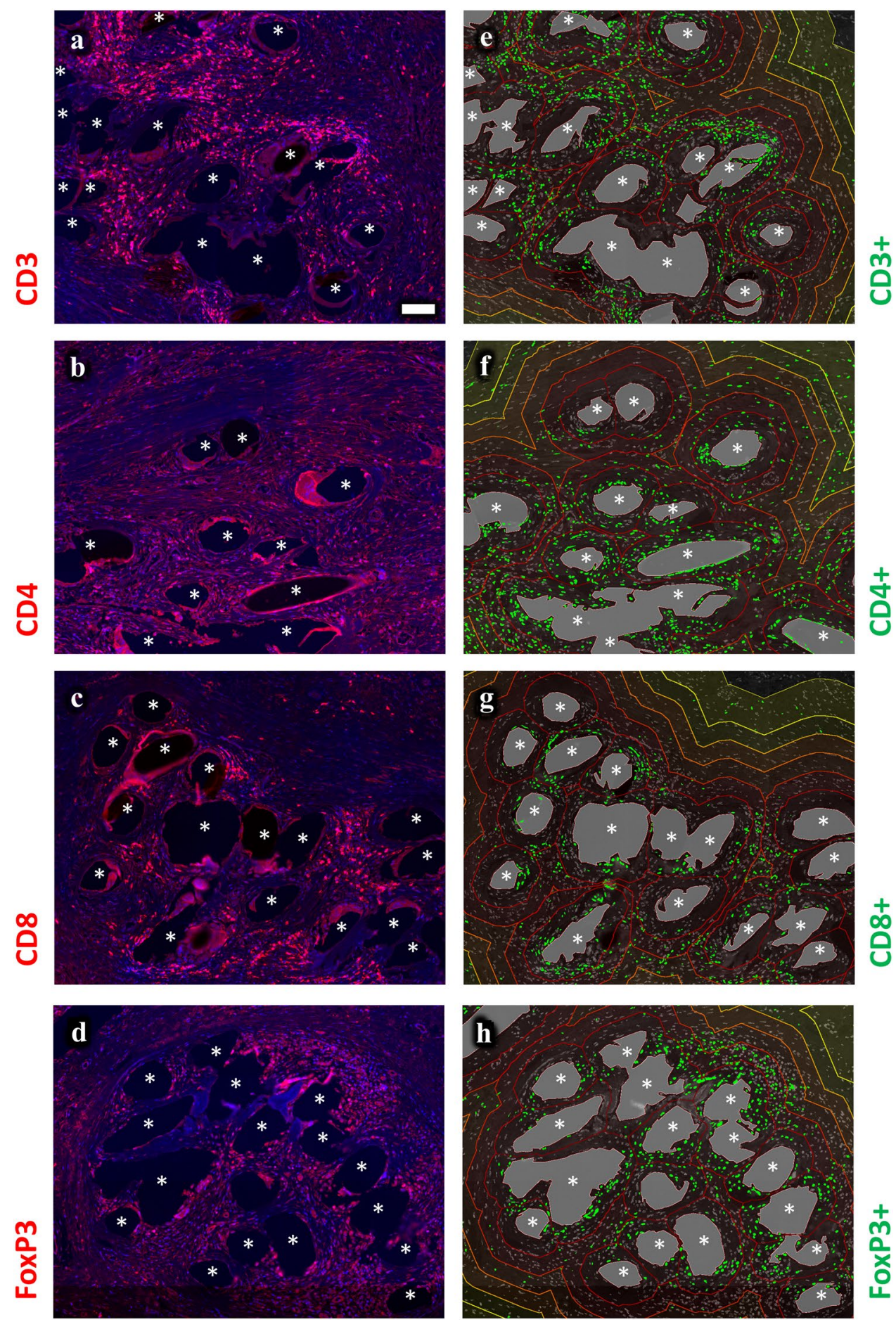

with co-expression of CD68; whereas cells transitioned to a more physiological "conventional" state at around $50-100 \mu \mathrm{m}$, demonstrating the successful shielding by the fibrotic capsule at the outer limitation of the FBG.

All specimens presented a pronounced FBR, which was restricted to the vicinity of the mesh fibers consisting of dense cellular infiltrates of mostly mononuclear cells. Using circular ROIs placed around mesh fibers, macrophages and $\mathrm{T}$ cells were found to be the predominant cell types within the FBG, which is in line with other studies on PP meshes [16, $17,22,23] . T_{\text {regs }}$ and $T_{h}$ were the most frequent $T$ subsets with $25 \%$ and $19.2 \%$, respectively, whereas $\mathrm{T}_{\mathrm{c}}$ were found at a lower rate of $13.5 \%$. The finding of more $T_{h}$ than $T_{c}$ is consistent with Tennyson et al. [16]. In contrast to our results, Artsen et al. and Tennyson et al. observed fewer $\mathrm{T}_{\text {regs }}$ than $T_{c}$ in human PP mesh explants from the pelvic floor 
Table 4 Spatial analysis of innate immune cells and the proportions of "conventional" cells participating in the foreign body reaction using Euclidean distance maps

\begin{tabular}{|c|c|c|c|c|c|c|}
\hline \multirow[t]{2}{*}{ Parameter ( $n=7$ PP meshes) } & \multicolumn{6}{|c|}{ Distance from mesh fibers } \\
\hline & $\begin{array}{l}\text { Zone1 } \\
000-050 \mu \mathrm{m}\end{array}$ & $\begin{array}{l}\text { Zone2 } \\
050-100 \mu \mathrm{m}\end{array}$ & $\begin{array}{l}\text { Zone3 } \\
100-150 \mu \mathrm{m}\end{array}$ & $\begin{array}{l}\text { Zone4 } \\
150-200 \mu \mathrm{m}\end{array}$ & $\begin{array}{l}\text { Zone5 } \\
200-250 \mu \mathrm{m}\end{array}$ & $\begin{array}{l}\text { Zone6 } \\
250-350 \mu \mathrm{m}\end{array}$ \\
\hline Cell density (cells/ $\mathrm{mm}^{2}$ ) & $4,418.2(80.2)$ & $3,602.8(98.6)^{\mathrm{a}}$ & $2,849.3(95.2)$ & $2,386.1(89.7)$ & $2,018.9(91.8)$ & $1,696.1(108.4)^{\mathrm{b}}$ \\
\hline$\% \mathrm{CD}_{11} \mathrm{~b}^{+}$ & $30.2(5.0)$ & $15.2(3.9)$ & $11.4(2.7)$ & $9.9(2.0)$ & $8.1(1.2)$ & $9.0(1.6)^{\mathrm{b}}$ \\
\hline $\begin{array}{l}\% \mathrm{CD} 11 \mathrm{~b}^{+} \mathrm{CD} 68^{-} / \mathrm{CD} 11 \mathrm{~b}^{+} \\
\text {"conventional" }\end{array}$ & $37.2(3.9)$ & $63.9(5.6)^{\mathrm{a}}$ & $67.5(5.4)$ & $68.0(6.3)$ & $66.2(6.2)$ & $65.7(4.8)^{\mathrm{b}}$ \\
\hline$\% \mathrm{CD} 6^{+}$ & $11.3(2.9)$ & $7.0(1.6)$ & $7.4(1.9)$ & $8.4(2.4)$ & $8.2(2.4)$ & $8.8(2.5)$ \\
\hline $\begin{array}{l}\% \mathrm{CD}^{+} 6^{+} \mathrm{CD} 68^{-} / \mathrm{CD} 56^{+} \\
\text {"conventional" }\end{array}$ & $18.1(2.9)$ & $61.9(9.5)^{\mathrm{a}}$ & $73.4(8.0)$ & $75.1(5.6)$ & $78.2(7.5)$ & $83.3(5.6)^{\mathrm{b}}$ \\
\hline$\% \mathrm{CD}^{+} 8^{+}$ & $45.4(1.5)$ & $20.1(1.4)^{\mathrm{a}}$ & $14.0(1.0)$ & $11.8(0.8)$ & $10.4(0.8)$ & $9.7(0.8)^{\mathrm{b}}$ \\
\hline
\end{tabular}

The cell density is defined as the mean number of cells per $\mathrm{mm}^{2}$. Percentages of single-positive (e.g., \% CD56 ${ }^{+}$) cells in relation to all cells and the proportions of "conventional" cells with respect to the total number of positive cells (e.g., \% CD56 ${ }^{+} \mathrm{CD} 68^{-} / \mathrm{CD}^{+} 6^{+}$). Hybrid cells with co-expression of CD68 were considered "disturbed". The data are presented as mean (SE). Significant differences between zones according to Mann-Whitney $U$ test: ${ }^{\mathrm{a}}$ zone1 and zone2, ${ }^{\mathrm{b}} \mathrm{zone} 1$ and zone6

Fig. 6 Spatial distribution of innate (CD68, CD11b, CD56) and adaptive $(\mathrm{CD} 3, \mathrm{CD} 4, \mathrm{CD} 8$, CD20, FoxP3) immune cells at the mesh-tissue interface. The bars represent the mean percentages of positive cells in each regional zone. Whiskers mark the SEs ( $n=7$ meshes). Cells with a mean staining intensity $>100$ are considered to be "positive". Innate immune cells are colored light blue and adaptive immune cells gray/ black (color figure online)

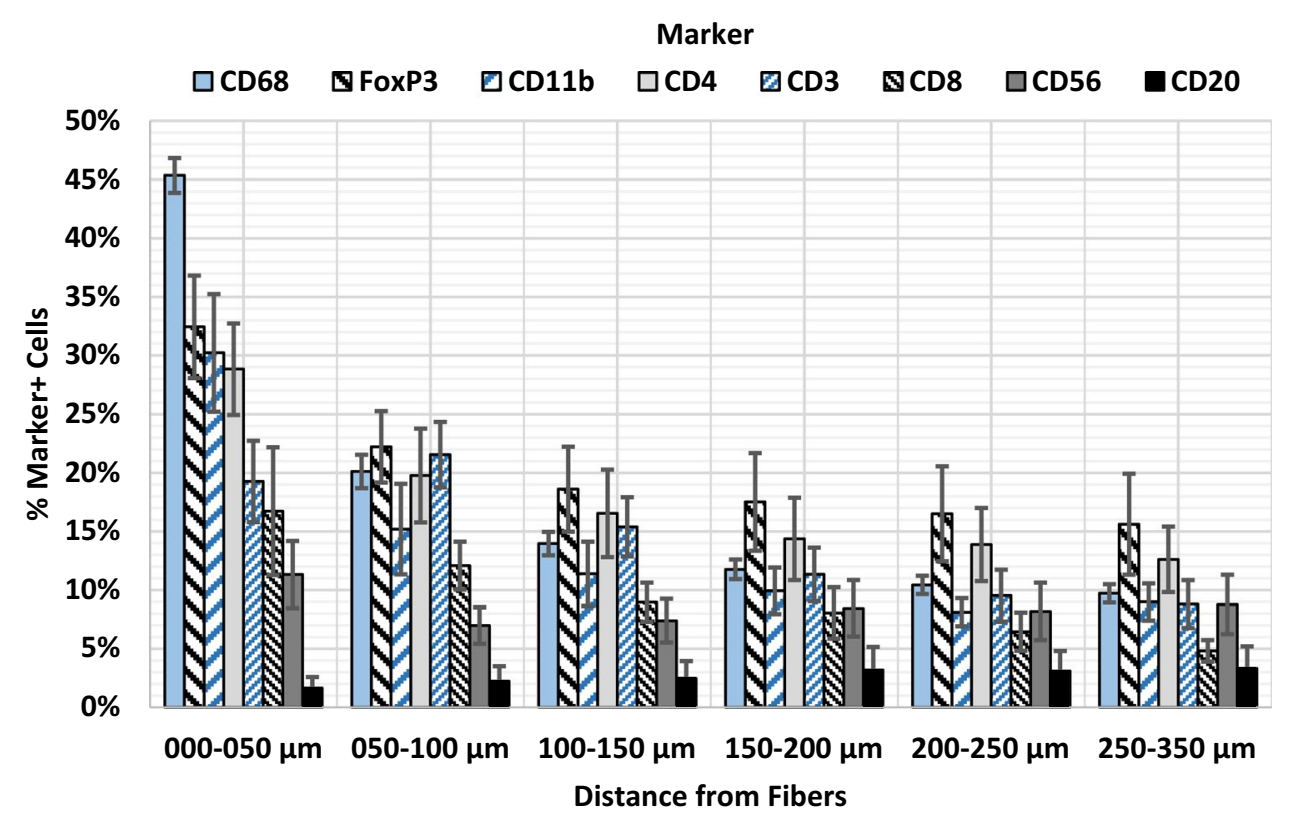

removed for pain or exposure [16, 17]. This difference may be explained by the intrinsic difficulty to quantify immunohistochemistry at little standardized samples. Quantification strongly depends on markers, the cutoff, and the location and size of the investigated region. Not least, the medical reason for mesh removal may interfere. Furthermore, there are likely differences in host reactions considering different anatomical locations, such as pelvic floor and abdominal wall $[20,24,25]$.

The role of FoxP3 ${ }^{+} \mathrm{T}_{\text {regs }}$ in the FBR is still controversial. It has been suggested that they promote a fibrotic response on the one hand and have an antifibrotic effect on the other [16, 17]. In general, $T_{\text {regs }}$ are known for their role in maintaining immune homeostasis via secretion of anti-inflammatory cytokines, expression of co-inhibitory molecules, modulation of antigen-presenting cells, and depletion of growth factors from the microenvironment [26]. Furthermore, they are capable of mediating several extra-immune functions, such as angiogenesis and tissue repair [26]. FoxP3 expression can be induced in various T cells, and has been reported in NK cells and macrophages, too [26]. With regards to the latter, the co-expression with $\mathrm{CD} 68$ in over $40 \%$ of FoxP $3^{+}$cells may indicate a potential role of FoxP3 in mesh-associated activation of macrophages. Furthermore, in light of the controversy whether $\mathrm{T}_{\text {regs }}$ promote or reduce fibrosis, the high level of FoxP $3^{+}$cells observed here, in combination with the 
Table 5 Spatial analysis of adaptive immune cells and the proportions of "conventional" cells participating in the foreign body reaction using Euclidean distance maps

\begin{tabular}{|c|c|c|c|c|c|c|}
\hline \multirow[t]{2}{*}{ Parameter ( $n=7$ PP meshes) } & \multicolumn{6}{|c|}{ Distance from mesh fibers } \\
\hline & $\begin{array}{l}\text { Zone 1 } \\
000-050 \mu \mathrm{m}\end{array}$ & $\begin{array}{l}\text { Zone2 } \\
050-100 \mu \mathrm{m}\end{array}$ & $\begin{array}{l}\text { Zone3 } \\
100-150 \mu \mathrm{m}\end{array}$ & $\begin{array}{l}\text { Zone4 } \\
150-200 \mu \mathrm{m}\end{array}$ & $\begin{array}{l}\text { Zone5 } \\
200-250 \mu \mathrm{m}\end{array}$ & $\begin{array}{l}\text { Zone6 } \\
250-350 \mu \mathrm{m}\end{array}$ \\
\hline Cell density (cells $/ \mathrm{mm}^{2}$ ) & $4,418.2(80.2)$ & $3,602.8(98.6)^{\mathrm{a}}$ & $2,849.3(95.2)$ & 2,386.1 (89.7) & 2,018.9 (91.8) & $1,696.1(108.4)^{b}$ \\
\hline$\% \mathrm{CD}^{+}$ & $19.3(3.5)$ & $21.6(2.8)$ & $15.4(2.5)$ & $11.3(2.3)$ & $9.5(2.2)$ & $8.8(2.0)^{\mathrm{b}}$ \\
\hline $\begin{array}{l}\% \mathrm{CD}^{+}{ }^{+} \mathrm{CD} 68^{-} / \mathrm{CD}^{+} \\
\text {"conventional" }\end{array}$ & $47.8(9.1)$ & $70.8(8.4)$ & $73.3(8.1)$ & $75.0(6.3)$ & $73.0(7.0)$ & $70.3(6.0)$ \\
\hline$\% \mathrm{CD}^{+}$ & $28.8(3.9)$ & $19.8(4.0)$ & $16.5(3.7)$ & $14.4(3.5)$ & $13.9(3.1)$ & $12.6(2.8)^{\mathrm{b}}$ \\
\hline $\begin{array}{l}\% \mathrm{CD} 4^{+} \mathrm{CD} 68^{-} / \mathrm{CD} 4^{+} \\
\text {"conventional" }\end{array}$ & $20.7(4.1)$ & $50.5(7.9)^{\mathrm{a}}$ & $54.6(6.5)$ & $56.2(5.6)$ & $58.4(5.5)$ & $57.5(7.4)^{\mathrm{b}}$ \\
\hline$\% \mathrm{CD}^{+}$ & $16.7(5.5)$ & $12.1(2.0)$ & $9.0(1.7)$ & $8.1(2.2)$ & $6.5(1.6)$ & $4.8(0.9)^{\mathrm{b}}$ \\
\hline $\begin{array}{l}\% \mathrm{CD} 8^{+} \mathrm{CD} 68^{-} / \mathrm{CD} 8^{+} \\
\text {"conventional" }\end{array}$ & $44.0(8.1)$ & $79.3(4.2)^{\mathrm{a}}$ & $83.6(3.4)$ & $78.3(4.6)$ & $72.2(4.9)$ & $77.5(4.4)^{\mathrm{b}}$ \\
\hline$\% \mathrm{CD} 20^{+}$ & $1.7(0.9)$ & $2.2(1.3)$ & $2.5(1.5)$ & $3.2(2.0)$ & $3.1(1.7)$ & $3.3(1.9)$ \\
\hline $\begin{array}{l}\% \mathrm{CD} 20^{+} \mathrm{CD} 68^{-} / \mathrm{CD} 20^{+} \\
\text {"conventional" }\end{array}$ & $57.3(12.1)$ & $91.8(6.8)$ & $92.4(3.0)$ & $95.3(2.8)$ & $85.2(10.8)$ & $95.1(2.5)$ \\
\hline$\% \mathrm{FoxP}^{+}$ & $32.4(4.4)$ & $22.2(3.1)$ & $18.6(3.6)$ & $17.5(4.2)$ & $16.5(4.1)$ & $15.6(4.3)^{\mathrm{b}}$ \\
\hline $\begin{array}{l}\% \text { FoxP3 }^{+} \mathrm{CD} 68^{-} / \mathrm{FoxP}^{+} \\
\text {"conventional" }\end{array}$ & $33.5(1.5)$ & $67.6(3.9)^{\mathrm{a}}$ & $79.9(3.4)$ & $83.7(3.3)$ & $87.3(2.0)$ & $90.7(2.2)^{\mathrm{b}}$ \\
\hline
\end{tabular}

The cell density is defined as the mean number of cells per $\mathrm{mm}^{2}$. Percentages of single-positive (e.g., \% $\mathrm{CD}^{+}$) cells in relation to all cells and the proportions of "conventional" cells with respect to the total number of positive cells (e.g., \% $\mathrm{CD} 3^{+} \mathrm{CD} 68^{-} / \mathrm{CD} 3^{+}$). Hybrid cells with co-expression of CD68 were considered "disturbed". The data are presented as mean (SE). Significant differences between zones according to Mann-Whitney $U$ test: ${ }^{\mathrm{a}}$ zone1 and zone2, ${ }^{\mathrm{b}}$ zone1 and zone6

Fig. 7 Dense clusters of B cells in the vicinity of the foreign body granuloma. Immunofluorescence labeling for macrophages (CD68, green) and B cells (CD20, red). Mesh fibers surrounded by macrophages with dense accumulations of B lymphocytes nearby, located around blood vessels (marked with '\#'). Locations of mesh fibers are marked with asterisks. Image of explant \#2 (color figure online)

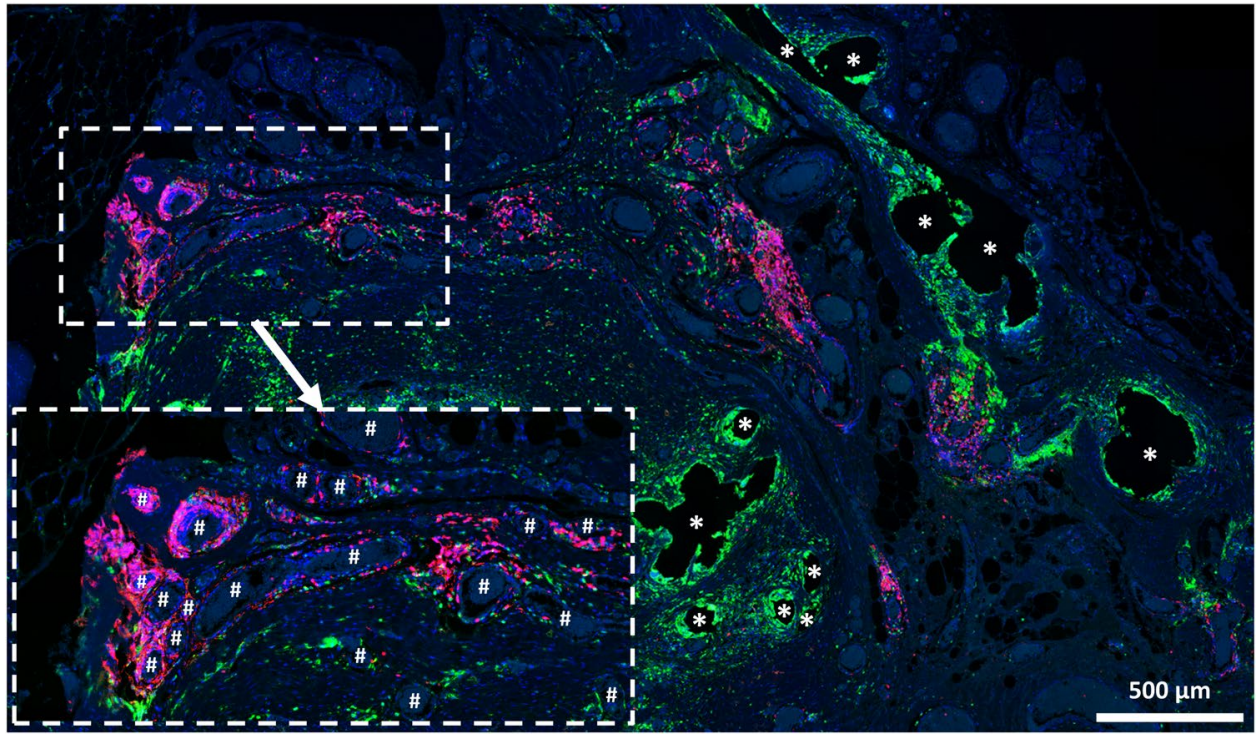

previous studies of the same specimens that clearly showed excessive collagen deposition [20], may suggest $T_{\text {regs }}$ are not antifibrotic in our samples.

Within the FBGs, CD20 $0^{+} \mathrm{B}$ cells were rare at about $5 \%$, which is in agreement with several studies [4, 23, 27], but interestingly dense clusters were frequently found near the FBGs accumulated around blood vessels. This finding may gain importance by the fact that $\mathrm{B}$ cells influence $\mathrm{T}$ cell responses and affect fibrosis through interactions with other cells including fibroblasts and macrophages [28]. Furthermore, proliferation of B cells in extramedullary environments allows for survival of self-reactive B cells, thereby increasing the potential for autoimmune pathology [29].

Another marker that has been studied is CD11b (also referred to as macrophage receptor 1 'Mac-1'), which is known for its expression on myeloid cells. CD11b mediates 
Fig. 8 "Hybrid" and "conventional" immune cells.

1. column Double stainings for macrophages (CD68) with FITC (green) and T cells (CD3), $\mathrm{T}_{\mathrm{h}}(\mathrm{CD} 4), \mathrm{T}_{\mathrm{c}}(\mathrm{CD} 8), \mathrm{T}_{\text {regs }}$ (FoxP3), NK cells (CD56), or myeloid cells (CD11b) with Cy5 (red). 2. column Backward gating of "hybrid" immune cells (green) and 3. column "Conventional" immune cells (green) on grayscale nuclei shades, respectively. Cells with a mean staining intensity $>100$ are considered to be "positive", scale bar $=100 \mu \mathrm{m}$ (color figure online)

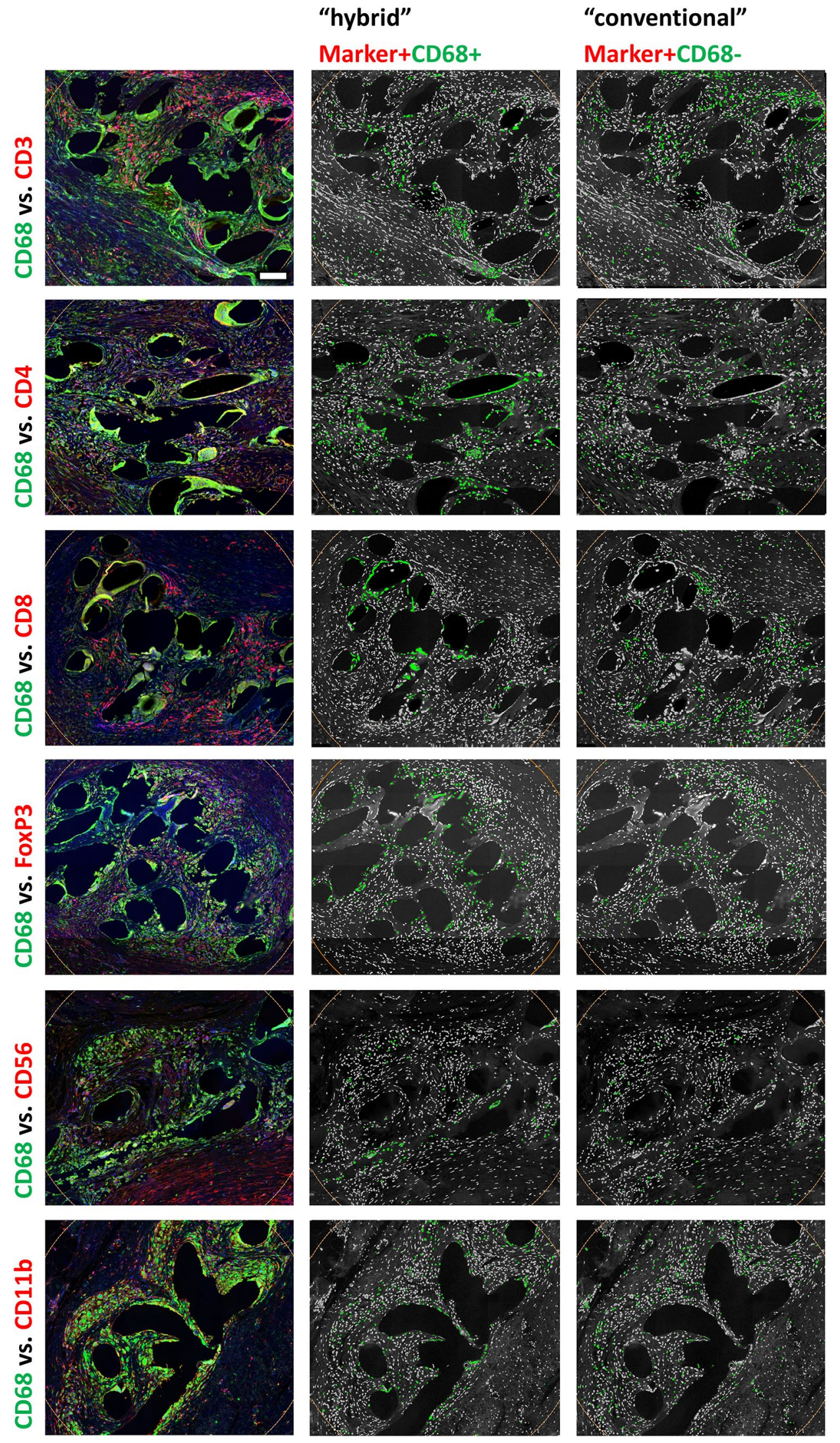

cellular adhesion, migration, and activation, and therefore plays a central role in inflammation [30]. It generally 
Fig. 9 Spatial characterization of "conventional" cells. Proportions of "conventional" cells (defined as cells not coexpressing CD68) in relation to the total number of positive cells (e.g., $\mathrm{CD} 4^{+} \mathrm{CD} 68^{-} / \mathrm{CD} 4^{+}$ for T-helper cells). The bars represent the mean proportions in each regional zone. Whiskers mark the SEs ( $n=7$ meshes). Cells with a mean staining intensity $>100$ are considered to be "positive". Innate immune cells are colored light blue and adaptive immune cells gray/ black (color figure online)

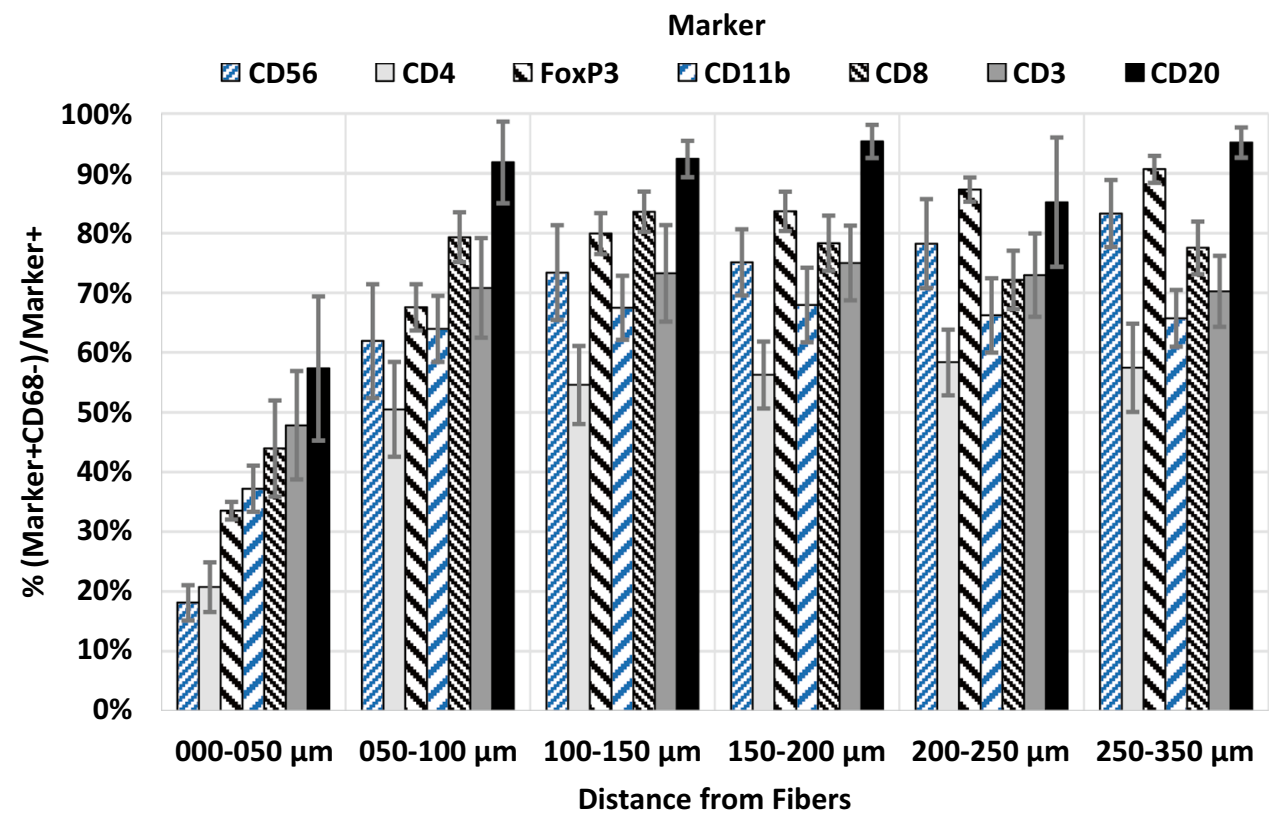

modulates pro- and anti-inflammatory signaling in cells [31]. As has been shown in human and murine cancers studies, tumor associated macrophages primarily exhibit an immunosuppressive/anti-inflammatory phenotype that significantly correlated with the expression of CD11b [32,33]. The high number of CD11 $\mathrm{b}^{+}$cells $(20.2 \%)$ observed in our samples, with half of them co-expressing CD68, underline the involvement of activated innate immune cells in the FBR. The considerable expression of $\mathrm{CD} 11 \mathrm{~b}$ indicates a rather anti-inflammatory function in this location, and corresponds with our previous data [20], where we have identified most macrophages within the granuloma as anti-inflammatory type expressing CD206 and CD163.

Spatial analysis using distance maps revealed that the proportions of positive cells for all immune cell types studied were highest in zone1 $(0-50 \mu \mathrm{m})$ or zone $2(50-100 \mu \mathrm{m})$, except for CD20 B cells. Consequently, these zones also contained the highest levels of CD68 co-expression and thus the lowest proportions of "conventional" cells. Most of these cells co-expressing CD68 are probably macrophages known for their remarkable plasticity that allows them to efficiently respond to environmental signals and change their phenotype and physiology [34]. In fact, previous studies have reported that macrophages can co-express several markers usually linked to other immune cells, such as CD3 [35-38], CD4 [39-42], CD8 [39, 41, 43], and FoxP3 [44]. Vice versa, other innate immune cell types, such as NK cells $[45,46]$ and adaptive immune cells, such as lymphocytes $[46,47]$ have been shown to express CD68. The observed co-expression of CD68 with lymphoid markers in cells governing the immune response indicate an unconventional activation/“disturbance" of cells due to the persistent stimulus by the meshes. This change of the functional landscape of the involved cells is similar to effects observed in infectious/inflammatory and tumor pathologies $[35,45,48]$. However, to decipher the underlying mechanisms of this heterogeneity, more thorough investigations using methods of extended multiplex stainings as well as lineage tracing are required.

For further spatially investigation of the FBR and to characterize the mesh-induced stimulus, we determined the proportions of "conventional" immune cells with expression of their specific immune cell marker and without co-expression of CD68 in each distance zone. In line with the high level of CD68 co-expression at the mesh-tissue interface, the proportions of "conventional" cells were lowest in zone1, but increased substantially in zone 2 for all cell types; and remained relatively constant thereafter. The highest percentages of innate $\mathrm{CD}^{+} 8^{+}$macrophages and innate "conventional" $\mathrm{CD} 11 \mathrm{~b}^{+} \mathrm{CD} 68^{-}$myeloid cells were found directly at the mesh-tissue interface $(0-50 \mu \mathrm{m})$, whilst highest percentages of "conventional" adaptive immune cells were found at greater distances. In addition, a significant decrease of cell density was observed from zone 1 to zone $3(0-150 \mu \mathrm{m})$. Taken together, these results illustrate the transition from dense cellular infiltrate to collagen-rich fibrotic capsule at about $50-100 \mu \mathrm{m}$ from the mesh fibers, and the attenuation of the mesh-induced stimulus by the fibrotic capsule, allowing most cells to maintain a "conventional" state. Several animal studies have investigated the size of the cellular infiltrate in relation to PP meshes [49-53]. The size of the cellular infiltrate obtained here with approximately $50 \mu \mathrm{m}$ diverges from data of these studies $(9-35 \mu \mathrm{m})$. There are several reasons for this. Amongst others, first, animal studies 
either lack a naturally occurring abdominal wall defect or an artificial defect in an otherwise intact abdominal wall is created. Second, there are inherent differences in the anatomy and meshes are not adapted to the physiology of animals. Finally, the size of the infiltrate strongly depends on the type of evaluation.

Based on the distributions of "conventional" cells and the cellular composition of the FBG with innate immune cells predominantly located centrally at the interface and adaptive immune cells peripheral, there seems to be some overlap with other granulomas, such as observed, for example, in sarcoidosis [10]. However, although the FBG of mesh always includes a fibrotic capsule, this is not always the case with sarcoidosis and foremost etiologies are different. Nevertheless, the FBG of mesh may serve as model to study the highly complex and coordinate interplay of the many diverse immune cell populations involved in granulomas. Interestingly, in the FBR of mesh, mainly innate immunity is studied as opposed to granulomatous inflammatory diseases. This is probably due to the natural time course of the FBR, the (early) observed predominance of macrophages, and time limit constraints in animal experiments.

Since the FBR is obviously an ongoing chronic process that never completely stops, risks may accumulate over the years, warranting caution of mesh utilization in younger patients. Given a sustained immunological response with abundant embedded $\mathrm{T}$ cells and $\mathrm{B}$ cell clusters questions its possible role in autoimmune diseases. As Cohen Terveart has postulated, patients may be at risk of developing (auto) immune disease when PP mesh is utilized; particularly, with pre-existing allergic disease [18]. Considering these facts, clearly, future attempts to enhance biocompatibility of meshes also need to consider the adaptive immunity.

Several limitations of our study have to be considered. The collection of explanted meshes comprised three different PP meshes with different textile properties (e.g., mechanical strength, pore sizes). Although the PTFE layer of the Ventrale ${ }^{\circledR}$ meshes has been spatially excluded with adjacent tissues, we cannot completely rule out any far-distant influence on the wound area. Furthermore, the selection of patients only included patients with recurrence of abdominal wall hernia after varying incorporation time. In addition to many possible confounders introduced by the complex staining protocol, the location and size of the investigated region will influence the results, as well. To compensate the latter, we used standardized $1 \mathrm{~mm}^{2}$ circular regions of interest (ROIs) that were placed around mesh fibers. In addition, we also used a Euclidean distance map algorithm that created six regional zones adjacent to the mesh fibers, allowing for spatially discrete quantification. Our choice of $1 \mathrm{~mm}^{2}$ ROIs and six regional zones covering $350 \mu \mathrm{m}$ from the mesh interface ensured that most of the FBG was included. By relating the number of positive cells to the total number of cells we created a robust, normalized measurement. For cells, the analysis of staining intensity only in the nucleus area cannot exclude positive staining based on some overlapping cytoplasmic membrane of adjacent cells, but the probability is considerably reduced by a cut thickness of $2 \mu \mathrm{m}$.

We applied a high cutoff value of 100 for the mean staining intensity of cells, as described [19], which allowed us to determine positive cells objectively and reliably and gives us the highest confidence for true positive detection. However, the consequence of this is that cells considered as positive need to have a high staining intensity, resulting in lower rates than would have been seen with lower cutoffs.

In conclusion, the findings of the present study clearly show that both the innate and the adaptive immune system participate in the long-term foreign body reaction to polypropylene meshes. $\mathrm{T}$ cells of the adaptive immune system were found with similar rates as macrophages. However, in concordance with the previous data [19], many cells at the mesh-tissue interface presented a "hybrid" pattern, as evidenced by signs of cross-lineage heterogeneity. Future attempts to enhance biocompatibility of meshes need to consider the adaptive immunity, focus on a reduction of the heterogeneous inflammatory infiltrate and the promotion of better wound healing.

Supplementary Information The online version contains supplementary material available at https://doi.org/10.1007/s10029-021-02396-7.

Funding Open Access funding enabled and organized by Projekt DEAL. The support by the Federal Ministry of Education and Research (FKZ 13GW0108B) enabled the acquisition of the TissueGnostics system.

Availability of data and material The raw data required to reproduce these findings are available on request from the authors.

\section{Declarations}

Conflict of interest $\mathrm{AD}$ as PhD student is an employee of FEG. PA and LD have no conflicts of interest. UK had research projects and consulting fees in collaboration with the mesh manufacturers Ethicon and FEG; expert testimony at lawsuits concerned with pelvic floor meshes; mesh patents with FEG. The financial disclosures listed result from their expertise, and none of them have tried to influence any part of the work for this manuscript.

Ethics approval All samples used in this study were redundant clinical specimens and their use was approved by the ethics committee at the University Hospital of the RWTH Aachen (EK 239/19).

Human and animal rights This article does not contain any studies with human participants or animals performed by any of the authors.

Informed consent For this retrospective review, formal consent is not required.

Open Access This article is licensed under a Creative Commons Attribution 4.0 International License, which permits use, sharing, 
adaptation, distribution and reproduction in any medium or format, as long as you give appropriate credit to the original author(s) and the source, provide a link to the Creative Commons licence, and indicate if changes were made. The images or other third party material in this article are included in the article's Creative Commons licence, unless indicated otherwise in a credit line to the material. If material is not included in the article's Creative Commons licence and your intended use is not permitted by statutory regulation or exceeds the permitted use, you will need to obtain permission directly from the copyright holder. To view a copy of this licence, visit http://creativecommons. org/licenses/by/4.0/.

\section{References}

1. Anderson JM, Rodriguez A, Chang DT (2008) Foreign body reaction to biomaterials. Semin Immunol 20:86-100. https://doi.org/ 10.1016/j.smim.2007.11.004

2. Krzyszczyk P, Schloss R, Palmer A, Berthiaume F (2018) The role of macrophages in acute and chronic wound healing and interventions to promote pro-wound healing phenotypes. Front Physiol. https://doi.org/10.3389/fphys.2018.00419

3. Klosterhalfen B, Junge K, Klinge U (2005) The lightweight and large porous mesh concept for hernia repair. Expert Rev Med Devices 2:103-117. https://doi.org/10.1586/17434440.2.1.103

4. Klinge U, Dietz U, Fet N, Klosterhalfen B (2014) Characterisation of the cellular infiltrate in the foreign body granuloma of textile meshes with its impact on collagen deposition. Hernia 18:571578. https://doi.org/10.1007/s10029-014-1220-1

5. Cadena AM, Fortune SM, Flynn JL (2017) Heterogeneity in tuberculosis. Nat Rev Immunol 17:691-702. https://doi.org/10.1038/ nri.2017.69

6. Ramakrishnan L (2012) Revisiting the role of the granuloma in tuberculosis. Nat Rev Immunol 12:352-366. https://doi.org/10. 1038/nri3211

7. Grunewald J, Grutters JC, Arkema EV et al (2019) Sarcoidosis. Nat Rev Dis Primers 5:45. https://doi.org/10.1038/ s41572-019-0096-X

8. Johnson CM, Hartman DJ, Ramos-Rivers C et al (2018) Epithelioid granulomas associate with increased severity and progression of Crohn's disease, based on 6-year follow-up. Clin Gastroenterol Hepatol 16:900-907.e1. https://doi.org/10.1016/j.cgh.2017. 12.034

9. Patterson P (2013) Hospitals share data to prevent colorectal SSIs. OR Manager 29(11):13

10. Starshinova AA, Malkova AM, Basantsova NY et al (2020) Sarcoidosis as an autoimmune disease. Front Immunol 10:2933. https://doi.org/10.3389/fimmu.2019.02933

11. Kosjerina Z, Zaric B, Vuckovic D et al (2012) The sarcoid granuloma: 'epithelioid' or 'lymphocytic-epithelioid' granuloma? Multidiscip Respir Med 7:11. https://doi.org/10.1186/ 2049-6958-7-11

12. Locke LW, Schlesinger LS, Crouser ED (2020) Current sarcoidosis models and the importance of focusing on the granuloma. Front Immunol 11:1719. https://doi.org/10.3389/fimmu.2020. 01719

13. Pagán AJ, Ramakrishnan L (2018) The formation and function of granulomas. Annu Rev Immunol 36:639-665. https://doi.org/10. 1146/annurev-immunol-032712-100022

14. Netea MG, Schlitzer A, Placek K et al (2019) Innate and adaptive immune memory: an evolutionary continuum in the host's response to pathogens. Cell Host Microbe 25:13-26. https://doi. org/10.1016/j.chom.2018.12.006
15. Mills CD, Kincaid K, Alt JM et al (2000) M-1/M-2 Macrophages and the Th1/Th2 Paradigm. J Immunol 164:6166-6173. https:// doi.org/10.4049/jimmunol.164.12.6166

16. Tennyson L, Rytel M, Palcsey S et al (2019) Characterization of the T-cell response to polypropylene mesh in women with complications. Am J Obstet Gynecol 220:187.e1-187.e8. https://doi. org/10.1016/j.ajog.2018.11.121

17. Artsen AM, Rytel M, Liang R et al (2019) Mesh induced fibrosis: the protective role of $\mathrm{T}$ regulatory cells. Acta Biomater 96:203210. https://doi.org/10.1016/j.actbio.2019.07.031

18. Cohen Tervaert JW (2018) Autoinflammatory/autoimmunity syndrome induced by adjuvants (Shoenfeld's syndrome) in patients after a polypropylene mesh implantation. Best Pract Res Clin Rheumatol 32:511-520. https://doi.org/10.1016/j.berh.2019.01. 003

19. Klinge U, Dievernich A, Tolba R et al (2020) CD68+ macrophages as crucial components of the foreign body reaction demonstrate an unconventional pattern of functional markers quantified by analysis with double fluorescence staining. J Biomed Mater Res. https://doi.org/10.1002/jbm.b.34639

20. Dievernich A, Achenbach P, Davies L, Klinge U (2020) Tissue remodeling macrophages morphologically dominate at the interface of polypropylene surgical meshes in the human abdomen. Hernia. https://doi.org/10.1007/s10029-020-02315-2

21. Serrano-Villar S, Moreno S, Fuentes-Ferrer M et al (2014) The CD4:CD8 ratio is associated with markers of age-associated disease in virally suppressed HIV-infected patients with immunological recovery: HIV, CD4:CD8 ratio and subclinical aging. HIV Med 15:40-49. https://doi.org/10.1111/hiv.12081

22. Karabulut A, Simavlı SA, Abban GM et al (2016) Tissue reaction to urogynecologic meshes: effect of steroid soaking in two different mesh models. Int Urogynecol J 27:1583-1589. https://doi.org/ 10.1007/s00192-016-3013-9

23. Brown BN, Mani D, Nolfi AL et al (2015) Characterization of the host inflammatory response following implantation of prolapse mesh in rhesus macaque. Am J Obstet Gynecol 213:668.e1-668. e10. https://doi.org/10.1016/j.ajog.2015.08.002

24. Pierce LM, Rao A, Baumann SS et al (2009) Long-term histologic response to synthetic and biologic graft materials implanted in the vagina and abdomen of a rabbit model. Am J Obstet Gynecol 200:546.e1-546.e8. https://doi.org/10.1016/j.ajog.2008.12.040

25. Nolfi AL, Brown BN, Liang R et al (2016) Host response to synthetic mesh in women with mesh complications. Am J Obstet Gynecol 215:206.e1-206.e8. https://doi.org/10.1016/j.ajog.2016. 04.008

26. Lu L, Barbi J, Pan F (2017) The regulation of immune tolerance by FOXP3. Nat Rev Immunol 17:703-717. https://doi.org/10. 1038/nri.2017.75

27. Heymann F, von Trotha K-T, Preisinger C et al (2019) Polypropylene mesh implantation for hernia repair causes myeloid celldriven persistent inflammation. JCI Insight 4:e123862. https://doi. org/10.1172/jci.insight. 123862

28. Zhu F, Bai X, Chen X (2017) B lymphocytes in renal interstitial fibrosis. J Cell Commun Signal 11:213-218. https://doi.org/10. 1007/s12079-017-0382-x

29. Cain D, Kondo M, Chen H, Kelsoe G (2009) Effects of acute and chronic inflammation on B-cell development and differentiation. J Investig Dermatol 129:266-277. https://doi.org/10.1038/jid.2008. 286

30. Solovjov DA, Pluskota E, Plow EF (2005) Distinct roles for the $\alpha$ and $\beta$ subunits in the functions of integrin $\alpha \mathrm{M} \beta 2$. J Biol Chem 280:1336-1345. https://doi.org/10.1074/jbc.M406968200

31. Faridi MH, Khan SQ, Zhao W et al (2017) CD11b activation suppresses TLR-dependent inflammation and autoimmunity in systemic lupus erythematosus. J Clin Investig 127:1271-1283. https://doi.org/10.1172/JCI88442 
32. Chittezhath M, Dhillon MK, Lim JY et al (2014) Molecular profiling reveals a tumor-promoting phenotype of monocytes and macrophages in human cancer progression. Immunity 41:815-829. https://doi.org/10.1016/j.immuni.2014.09.014

33. Geraghty T, Rajagopalan A, Aslam R et al (2020) Positive allosteric modulation of $\mathrm{CD} 11 \mathrm{~b}$ as a novel therapeutic strategy against lung cancer. Front Oncol 10:748. https://doi.org/10.3389/fonc. 2020.00748

34. Mosser DM, Edwards JP (2008) Exploring the full spectrum of macrophage activation. Nat Rev Immunol 8:958-969. https://doi. org/10.1038/nri2448

35. Rodriguez-Cruz A, Vesin D, Ramon-Luing L et al (2019) CD3+ macrophages deliver proinflammatory cytokines by a CD3- and transmembrane TNF-dependent pathway and are increased at the BCG-infection site. Front Immunol 10:2550. https://doi.org/10. 3389/fimmu.2019.02550

36. Beham AW, Puellmann K, Laird R et al (2011) A TNF-regulated recombinatorial macrophage immune receptor implicated in granuloma formation in tuberculosis. PLoS Pathog 7:e1002375. https://doi.org/10.1371/journal.ppat.1002375

37. Chavez-Galan L, Vesin D, Blaser G et al (2019) Myeloid cell TNFR1 signaling dependent liver injury and inflammation upon BCG infection. Sci Rep 9:5297. https://doi.org/10.1038/ s41598-019-41629-9

38. Fuchs T, Hahn M, Riabov V et al (2017) A combinatorial $\alpha \beta$ T cell receptor expressed by macrophages in the tumor microenvironment. Immunobiology 222:39-44. https://doi.org/10.1016/j.imbio. 2015.09.022

39. Baba T, Ishizu A, Iwasaki S et al (2006) CD4+/CD8+ macrophages infiltrating at inflammatory sites: a population of monocytes/macrophages with a cytotoxic phenotype. Blood 107:20042012. https://doi.org/10.1182/blood-2005-06-2345

40. Zhen A, Krutzik SR, Levin BR et al (2014) CD4 ligation on human blood monocytes triggers macrophage differentiation and enhances HIV infection. J Virol 88:9934-9946. https://doi.org/10. 1128/JVI.00616-14

41. Gibbings D, Befus AD (2009) CD4 and CD8: an inside-out coreceptor model for innate immune cells. J Leukoc Biol 86:251-259. https://doi.org/10.1189/jlb.0109040

42. Sattentau QJ, Stevenson M (2016) Macrophages and HIV-1: an unhealthy constellation. Cell Host Microbe 19:304-310. https:// doi.org/10.1016/j.chom.2016.02.013

43. Hiraki K, Park I-K, Kohyama K, Matsumoto Y (2009) Characterization of CD8-positive macrophages infiltrating the central nervous system of rats with chronic autoimmune encephalomyelitis. J Neurosci Res 87:1175-1184. https://doi.org/10.1002/jnr.21924
44. Devaud C, Yong CSM, John LB et al (2014) Foxp3 expression in macrophages associated with RENCA tumors in mice. PLoS ONE 9:e108670. https://doi.org/10.1371/journal.pone.0108670

45. Niavarani SR, Lawson C, Bakos O et al (2019) Lipid accumulation impairs natural killer cell cytotoxicity and tumor control in the postoperative period. BMC Cancer 19:823. https://doi.org/10. 1186/s12885-019-6045-y

46. Hameed A, Hruban RH, Gage W et al (1994) Immunohistochemical expression of CD68 antigen in human peripheral blood T cells. Hum Pathol 25:872-876. https://doi.org/10.1016/0046-8177(94)90005-1

47. Gottfried E, Kunz-Schughart LA, Weber A et al (2008) Expression of CD68 in non-myeloid cell types. Scand J Immunol 67:453-463. https://doi.org/10.1111/j.1365-3083.2008.02091.x

48. Oakley MS, Chorazeczewski JK, Aleshnick M et al (2018) TCR $\beta$ expressing macrophages induced by a pathogenic murine malaria correlate with parasite burden and enhanced phagocytic activity. PLoS ONE 13:e0201043. https://doi.org/10.1371/journal.pone.0201043

49. Lambertz A, van den Hil LCL, Schöb DS et al (2016) Analysis of adhesion formation of a new elastic thermoplastic polyurethane (TPU) mesh in comparison to polypropylene (PP) meshes in IPOM position. J Mech Behav Biomed Mater 53:366-372. https:// doi.org/10.1016/j.jmbbm.2015.08.036

50. Gerullis H, Klosterhalfen B, Borós M et al (2013) IDEAL in meshes for prolapse, urinary incontinence, and hernia repair. Surg Innov 20:502-508. https://doi.org/10.1177/1553350612472987

51. Veleirinho B, Coelho DS, Dias PF et al (2014) Foreign body reaction associated with PET and PET/chitosan electrospun nanofibrous abdominal meshes. PLoS ONE 9:e95293. https://doi.org/ 10.1371/journal.pone.0095293

52. Binnebösel M, Klink CD, Otto J et al (2010) Impact of mesh positioning on foreign body reaction and collagenous ingrowth in a rabbit model of open incisional hernia repair. Hernia 14:71-77. https://doi.org/10.1007/s10029-009-0580-4

53. Conze J, Junge K, Weiß C et al (2008) New polymer for intraabdominal meshes-PVDF copolymer. J Biomed Mater Res B Appl Biomater 87B:321-328. https://doi.org/10.1002/jbm.b.31106

Publisher's Note Springer Nature remains neutral with regard to jurisdictional claims in published maps and institutional affiliations. 